work, though of course in a much greater degree to engineers. By its means a considerable advance has been made in our knowledge of the distribution of stress intensities at discontinuities, where very little exact information was previously available. It is particularly useful in the stress analysis of fusion joints, in which it is, as a rule, a fallacy to assume that stress distributions can be determined by applying elementary methods. In this paper, Dr. Coker takes the connexion of two steel plates in line by means of a V fusion weld as a typical example of the incalculable stresses which can be determined by photo-elastic analysis. He describes the apparatus required and concludes with a description of a detached photo-elastic laboratory made by a small addition to a medium-sized house.

\section{The World's Greatest Highway}

THE Inter-American Highway from Alaska and Canada in the north to Chile, the Argentine and Brazil in the south, is now, according to an article in Roads and Road Construction of February, having its gaps filled in on the maps and plans of engineers. At present, 4,500 miles of its length are passable by motor-cars in all weathers. The finished sections are in Canada, the United States, Mexico and Panama, and parts of all-weather roads are completed in Alaska, Costa Rica, Salvador, Guatemala, Colombia and Brazil. Highways passable in dry weather cover the greater part of the international highway route. The South American portion of the highway offers a great variety of scenery. There are the jungles of Colombia and Brazil, the sea coasts of Peru and Chile, the magnificent heights of the Andes and the broad expanse of the Argentine pampas. A thousand miles of this highway will be at elevations of 5,000 $10,000 \mathrm{ft}$. The international project is to open up a through route for the highway tourist between North and South America. It will be of special value to citizens of the United States living in the Panama zone. The 250 miles of improved road in Panama have already been largely patronised by the residents of the Canal Zone for recreational travel, and a through highway to the north would be very attractive to them. The Central American section makes it possible to open up large areas for agricultural and commercial development and so promote their economic welfare. At present, access is mainly by steamer to the ports and thence by rail, highway or aeroplane. Pan-American Airways provides a service throughout the length of Central America, paralleling the future line of the Inter-American Highway on the Pacific slope of the divide.

\section{Post Office Publicity}

THE present-day policy of the Post Office is based on a recognition of the fact that the Post Office is not only a Government Department, but is also one of the largest businesses in Great Britain. In pursuance of this recognition, recent developments have included the establishment of a Public Relations Department, with an organisation for employing all the most modern methods of publicity at its disposal. An interesting account of the policy being followed by this department is given in a recently published pamphlet entitled, "Post Office Publicity". This pamphlet is the eighth of a series of Post Office Green Papers (London: H.M. Stationery Office. $6 d$. net), previous issues of which have dealt with the air mail service and with various aspects of telegraph and telephone communication. The text of the pamphlet has been adapted from a lecture recently given by Sir Stephen Tallents, Public Relations Officer of the General Post Office, and it is illustrated by a selection of photographs and reproductions of posters and pamphlets already issued by the Post Office. This pamphlet shows how recent advances in the arts of press advertising and exhibition display and the arrival of new forms of communication in films and broadcasting have coincided with the growth of the new need of correctly-balanced publicity. The methods by which the Post Office is pursuing these purposes are clearly described. These include press advertising, the supply of posters of high artistic quality for public display and for use in schools, and the participation in public exhibitions of various kinds, and the temporary leasing of shops in important centres for the display of Post Office activities and equipment. Finally, the G.P.O. Film Unit produces and circulates films which illustrate vividly the great variety of Post Office work.

\section{Canalisation of the Upper Mississippi}

AN article in the Scientific American of February by Mr. S. G. Roberts describes the important work now being done under the United States Army engineers for the improvement of the navigation of the Upper Mississippi River. Some years back it was considered that a channel six feet deep at low water could be maintained by dredging and contraction works, but this proved to be impracticable. In 1931, therefore, it was decided to canalise the whole length of the river between St. Louis and the 'twin-cities' of Minneapolis and St. Paul, a distance of about 650 miles, so as to give a minimum depth of 9 feet. For this purpose, 27 dams are being built, each having locks 110 feet wide and 600 feet long. The dams are provided with spillways and roller gates suitable for contending with fields or floes of ice, which sometimes attain a thickness of 2 feet. The object of the scheme is to provide for the direct shipment of cargoes from Minneapolis and other places direct to New Orleans by means of flotillas of barges which will carry as much as 14,000 tons, and will be towed through the locks without changing formation. The work was begun about three years ago and is expected to be completed in 1938 at a cost of $124,000,000$ dollars. "There is every reason to believe," says Mr. Roberts, "that the work now under way will give to the Mississippi valley a trunk-line water route that will mean to the vast region served by it what the Rhine has long been to Central Europe. From Minneapolis to the sea, the Mississippi has a length of 1,950 miles; and the run from Minneapolis to New Orleans is 1,840 miles. 
From the head of navigation on the Rhine to the sea, the distance is 445 miles. Therefore the Mississippi offers a water outlet to a far more extensive region than does the Rhine; and the potential wealth of the American domain is infinitely greater and in some respects more varied."

\section{Cold-Storage Plant in Madrid}

WI'TH the aid of cold-storage plant it is possible to regulate the supply of perishable foodstuffs to a city so that, whatever the season, the supply may be sufficient. A privately owned cold-storage building has been erected in Madrid with this end in view. 0 . Rhunke gives a description of the plant used in this building in the Escher-Wyss News of April. A five-storied building was constructed in the immediate vicinity of the principal markets, with the railway track on one side and the Calle de Toledo on the other. The level of the railway is $23 \mathrm{ft}$. above the level of the street, so that goods are unloaded from the railway into a chute and delivered into the street from the ground floor. Ten thousand cubic metres are provided for storage for eggs, fruit and fish. The main cooling is by conditioned air with brinecirculated cooling in addition. The temperature and humidity of all the cooling rooms have to be kept within prescribed limits. The used air is cleared out several times every day and ozonising is employed. Special care has to be taken to prevent any interruption of the cooling process taking place. A cooling capacity of thirteen million British thermal units per day is required. It was at first thought that such a spacious building would considerably exceed the needs of the city, but three months after the opening practically all the space was utilised.

\section{East Malling Research Station}

THe twenty-second annual report, for the year 1934, of the East Malling Research Station, has just been published (pp. 241. 4s. net. May 1935). The Station is maintained by the Kent Incorporated Society for Promoting Experiments in Horticulture, with various grants from the Ministry of Agriculture and Fisheries. A 22-page supplement describes the more administrative side of the Station, and leaves the main volume free to set forth the research findings during the past year. These are, perhaps, even more numerous than usual, for a determined effort has been made to elucidate more fully the problems of insecticides and fungicides. Section 1 of the report describes the experimental farm, and is contributed by Messrs. J. Amos, F. H. Beard, M. H. Moore and A. C. Painter, with a foreword by the director, Mr. R. G. Hatton. Section 2 is a general review of research work, with summaries of papers published during the year. It is compiled by numerous members of the staff. The third section, on preliminary research reports, occupies most of the volume. Truly is the East Malling Research Station justifying its comparison, voiced by H.R.H. the Duke of York, to a standard apple tree, which, once established on good soil, would "continue to flourish and yield excellent fruit".

\section{Farm Machinery}

The favourable reception that attended the publication of the first volume of "Farm and Machine" issued by the Institute for Research in Agricultural Engineering, Oxford, last year, has led to the decision that an annual issue would be justified. Vol. 2, which has recently appeared (2s. 6d.), contains like its predecessor the report of the Institute for the year under review and also a collection of miscellaneous papers on agricultural engineering. The chief event of the year has been the removal of the Institute into its new quarters in Parks Road, a building well suited for the indoor work and provided with excellent workshop and stores accommodation. The testing of various new types of agricultural machinery naturally takes a prominent place in the work of the Institute, but research on the theoretical side is also carried out, from which important advances have already been made. The titles of some of the miscellaneous articles such as market garden tractors, farm electricity tariffs, the mode of action of mole drains, sugar beet harvesting, implements for regenerating grassland need only be quoted to show that the volume is likely to be of help and interest to a wide section of the farming community.

\section{Rare Developmental Condition in a Boy}

A note by Science Service, of Washington, D.C., states that a 'dog-boy' four years old is living in Kharkov, U.S.S.R. His face and body are entirely covered with long blond hair, coarse and a little wavy. The child is otherwise normal mentally and physically except for rickets, which is being treated in the hospital. The relatives are all normal so far as known. This very rare condition is known as hypertrichosis universalis. Some thirty such families have been recorded, most of them from Russia. In certain cases reported from India, the hair was dark. The condition is a developmental defect, in which the prenatal lanugo is not shed. It may be accompanied by faulty teeth and nails. Once the condition has appeared, it is likely to recur in the next generation. An effort should be made to determine whether the family producing this child is related in any way to the previously recorded Russian families.

\section{Bibliography of Seismology}

IN a recent issue of Nature (135, 1070 ; June 29), a brief notice was given of the "Bibliography of Seismology" for the year 1934 prepared by the Dominion Observatory of Ottawa. In that note, it was pointed out that Great Britain is not represented in the list of collaborators. We have received a letter from Dr. F. J. W. Whipple, Kew Observatory, in which he suggests that this omission may be taken to imply that the works of British seismologists are ignored in the Bibliography, and he states that in the last quarterly number there are seven references to such publications. On the other hand, in the United States, there are eleven collaborators, who refer to forty memoirs written in that country. The test as regards completeness is not, however, the actual number of memoirs noticed, so much as the 